\title{
African Firms Manufacturing and Economic development: Is Africa Effectively Competing in Manufacturing in the World Market?
}

\author{
Agu, Osmond Chigozie ${ }^{1}$, Mbah, Stella Ada ${ }^{2}$ \\ Lecturer, Department of Economics and Development Studies Federal University, Oye-Ekiti, Nigeria
}

\begin{abstract}
This paper examines the status of industrial development in Africa with a focus on the identification of stylized facts associated with African manufacturing. It also provides an analysis of past attempts at promoting industrial development in the region and the lessons learned from these experiences. Panel data (combination of Cross sectional and Time series analysis) is applied on the data obtained by UNIDO from developing countries spanning from 1980-2010. After gaining political independence, which occurred mainly in the 1960s, most African countries started to promote industrialization. The emphasis on industrialization was based on the political conviction by African leaders that it was necessary to ensure self-reliance and reduce dependence on advanced countries. Furthermore, there was the expectation that industrialization would hasten the transformation of African countries from agricultural to modern economies, create employment opportunities, raise incomes as well as living standards, and reduce vulnerability to terms of trade shocks resulting from dependence on primary commodity exports. But during the 1970s, with successive oil shocks and an emerging debt problem, it started to become clear that import substitution industrialization was not sustainable. With the introduction of structural adjustment programmes in the 1980s, African countries curtailed specific policy efforts to promote industrialization and focused on removing anti-export biases and furthering specialization according to comparative advantage. It was expected that competitive pressures would revitalize economic activity by leading to the survival of the fittest. But whilst these policies were certainly intended to have structural effects, the conventional view is that they did not boost industrialization in the region. Efforts to promote industrial development in Africa should be centered on (a) promoting scientific and technological innovation, (b) creating linkages in the domestic economy, (c) fostering entrepreneurship, $(d)$ improving government capabilities, (e)adopting appropriate monetary and fiscal policies.
\end{abstract}

Keywords: Industrialization, Self reliance, oil shocks, Employment generation, Primary commodity.

\section{Introduction}

Over the past two decades, the global environment has changed significantly in many aspects. International trade is increasingly under regulation in ways that limit the policy space available to governments (UNCTAD, 2004). Developing countries are beginning to play important roles in the global market for manufactured goods, with consequences for the ability of African countries to penetrate export markets. In addition, concern for climate change is generating interest in the use of environmentally friendly technologies and methods of production. Furthermore, production is increasingly being fragmented and located across national borders, thereby intensifying competition. The global financial and economic crisis has also raised serious concerns about the viability of unregulated markets as determinants of economic development. The strategic design and implementation of Africa's industrial development programmes will have to take into account these new realities because they have implications for the choice and feasibility of policies to promote industrialization.

The analysis of Africa's industrial performance suggests that most countries in the region are still struggling to develop a competitive manufacturing sector. But there is at the same time a growing consensus that African countries have to diversify their production and export patterns to reduce vulnerability to shocks, to boost growth, to provide employment opportunities and to enhance their integration into the global economy. Against this background, there is an increasing interest amongst African policymakers in the potential role of industrial policy in the region. But at the same time they are searching for a new approach which does not repeat the mistakes of the past.

There is no convergence of views on what should constitute industrial policy. In this paper, the term is used to describe government measures aimed at improving the competitiveness and capabilities of domestic firms and promoting structural transformation. Industrial policy involves a combination of strategic or selective interventions aimed at propelling specific activities or sectors, functional interventions intended at improving the workings of markets, and horizontal interventions directed at promoting specific activities across sectors 
(Lall and Tuebal, 1998). An important aspect of a new industrial policy is that it should be part of a broader productive development strategy which is concerned with enhancing capital accumulation and knowledge accumulation.

The paper advocates a strategic approach to industrial policymaking and it is tailored to specific country circumstances. A one-size-fits-all approach has not worked in the past and will simply not work in the future. Country specificities necessitate flexibility in the strategy design and also the policymaking process. A new industrial policy should not follow a universal blueprint approach. Instead, it has to build on the initial conditions and deliberately target the country specific economic constraints that are the key obstacles to a sustained industrial growth path. Taking into account the importance of country specificities, an industrial strategy has to be designed on the basis of the country's current situation or starting position. Most importantly, the already existing manufacturing activities have to be taken

Into consideration as well as differing development stages, endowment structures, country and population size, etc. This implies that the design of an industrialization strategy has to be based on a thorough evaluation of the country's present industrial base, i.e. an industrial diagnosis.

\subsection{Objective Of The Study} manufacture.

The objective of this study is to empirically $\mathrm{x}$-ray the contributions of Africa firms to the world

\subsection{Statement Of The Problem}

The commitment of African countries to industrialization is evident at the regional level. Despite all the giant strides and commitments of African policy makers in the region, for example, The New Partnership for Africa's Development (NEPAD) adopted by African leaders in 2001 identified economic transformation through industrialization as a critical vehicle for growth and poverty reduction in the region. Furthermore, in February 2008, African Heads of State adopted a Plan of Action for the Accelerated Industrial Development of Africa (AIDA). At the 2011 CAMI organized by the African Union, the United Nations Industrial Development Organization (UNIDO), the Government of Algeria and the participants deliberated on the effective implementation of AIDA and how to achieve sustainable industrial development in Africa. The new commitments build on past regional initiatives such as the Lagos Plan of Action (1980), the Abuja Treaty establishing the African Economic Community (adopted in 1991), and the Alliance for Africa's Industrialization (1996), which also stressed the need for diversification and economic transformation as a critical vehicle for achieving African self-reliance, yet Africa is still lagging in world manufacture.

The renewed commitment to promoting industrial development in Africa is timely. African countries have been buffeted by three very serious and interrelated external shocks, namely hikes in food prices, increases in energy prices and the global financial and economic crisis triggered by events in the United States housing market in the fall of 2007. The economic and social costs of the triple crises in Africa have been quite substantial. The triple crises have refocused attention on Africa's high vulnerability to external shocks and the need for policymakers to take urgent action to diversify their production and export structure to build resilience to shocks. The region is currently the least diversified in the world and, more importantly, has made relatively very slow progress in this area in the last two decades.

\subsection{Hypothesis}

H0: There is no significant contribution of manufacturing exports to total exports

of Africa Manufacture to the overall world manufactures.

H0: There is no significant contribution of more technology intensive manufacturing exports to total world manufactures.

\section{Literature Review}

Some work has been done on the struggles of African countries to favourably compete with the other countries in manufacturing which these are a few of them.

\subsection{The Strategic Importance of Manufacturing}

The industrial sector is, in general, defined as being composed of manufacturing, mining and construction. However, there is a large literature that suggests that the manufacturing sector is the component of industry that presents greater opportunities for sustained growth, employment and poverty reduction in Africa. The United Nations Department of Economic and Social Affairs (DESA) defines manufacturing as the physical or chemical transformation of materials, substances or components into new products. The materials, substances or components transformed are raw materials that are products of agriculture, forestry, fishing, mining or quarrying or products of other manufacturing activities. Substantial alteration, renovation or reconstruction of goods is generally considered to be manufacturing. The strategic role of manufacturing in the development 
process can be ascribed to a variety of factors. The first is that technology and innovation are crucial for economic development and manufacturing has historically been the main source of innovation in modern economies (Lall, 2005; Gault and Zhang, 2010). The research and development activities of manufacturing firms have been the key source of technological advances in the world economy (Shen, Dunn and Shen, 2007). Furthermore, manufacturing is a major conduit for diffusion of new technologies to other sectors of the economy.

Another advantage of manufacturing relative to other sectors is that there are very strong linkage and spill-over effects associated with manufacturing activities. For example, it is well known that manufacturing is a critical source of demand for other sectors. In particular, manufacturing firms are important consumers of banking, transport, insurance and communication services. Furthermore, manufacturing provides demand stimulus for growth of the agricultural sector. Consequently, manufacturing has high forward and backward linkages, thereby contributing to domestic investment, employment and output in the development process. Manufacturing is also attractive because, following Engel's law, the share of agriculture in total household expenditure falls as per capita income rises while the share of manufactures increases. This implies that manufactures offer significant opportunities for export market expansion and therefore is a key driver of growth in merchandise trade. Interestingly, countries that have derived significant benefits from the tremendous increase in merchandise trade over the past three decades are those that have been able to increase their exports of dynamic products, particularly manufactures, with high income elasticity of demand. Consequently, what a country produces and exports matters (Hausmann, Hwang and Rodrik 2007).

Manufacturing also has a higher potential for employment creation relative to agriculture and traditional services. In particular, the existence of diminishing returns to scale in agriculture (due to fixed factors such as land) implies that the opportunities for employment growth in the sector are limited. Consequently, as a country's population grows and urbanization takes place, there is the need for growth in manufacturing employment to absorb labour displaced from agriculture.

\subsection{Stages of industrial development in Africa}

While there are differences across countries in terms of the starting dates for the industrialization programmes, it is evident that industrial development in Africa has gone through three broad phases or stages since independence. The first phase which began in the 1960s and ended in the late 1970s is the import substitution industrialization (ISI) phase. The second phase, which represents the structural adjustment programme (SAP) phase, began in the early 1980s and ended in the late 1990s. The third phase, the poverty reduction strategy papers (PRSP) phase, began in 2000.

\subsubsection{The Import Substitution Industrialization ( ISI) phase}

The ISI phase of industrial development in Africa began after political independence in the 1960s up until the late 1970s. As in other developing country regions, ISI in Africa started with the domestic production of consumer goods that were previously imported. The idea was that the domestic markets for these goods already existed and could form the basis for initiating an industrialization programme. While the initial focus was on consumer goods, there was the expectation that, as the industrialization process proceeds, there will also be domestic production of intermediate and capital goods needed by the domestic consumer goods industry.

There was also the expectation and hope that the replacement of imported goods with domestically produced goods would, over time, enhance self-reliance and help prevent balance-of-payments problems. The implementation of ISI involved substantial government support as well as protection of domestic firms from foreign competition. In particular, domestic infant industries were identified and nurtured through trade protection and other domestic economic policies. This was rationalized on the grounds that domestic firms have the potential to be competitive but require a temporary period of protection before they could withstand international competition.

\subsubsection{The Structural Adjustment Programmes (SAP) phase}

The SAP phase in Africa began in the early 1980s and ended in the late 1990s. In particular, its origin could be traced back to the early 1980s, when African countries experienced severe balance of payments crisis resulting from the cumulative effects of the oil crisis, the decline in commodity prices, and the growing import needs of domestic industries. In response to the crisis, many countries sought financial assistance from the International Monetary Fund (IMF) and the World Bank. The IMF/World Bank interpretation of the crisis and Africa's industrial development problems were that it had to do with poor domestic policies and so the recommendation was that African countries adopt SAPs (Soludo, Ogbu and Chang, 2004). This interpretation and policy prescription was based on the findings of the Berg Report on Accelerated Development in SubSaharan Africa: An Agenda for Action published by the World Bank in 1981. The report argued that Africa's economic and industrial performance was poor because of policy inadequacies in the form of overvalued 
exchange rates, interest rate controls, overemphasis on industry at the expense of agriculture, and trade protectionism. In addition, the report was of the view that Africa's comparative advantage lay in agriculture and not industry. Consequently, it did not share the popular view among African policymakers that industry should be promoted through deliberate government intervention.

African countries that adopted SAPs were expected to implement certain policy reforms as a condition for receiving financial assistance from the IMF and the World Bank. The policy conditions included among other things: (a) deregulation of interest rates; (b) trade liberalization; (c) privatization of State-owned enterprises or (parastatal) (d) withdrawal of government subsidies; and (e) currency devaluation.

One of the key objectives of SAPs was to reduce the role of the State in the industrialization and development process and give market forces more room in the allocation of resources. The assumption was that markets are more efficient than the State in resource allocation and that the appropriate role of the latter should be to provide an enabling environment for the private sector to flourish. Critics of SAP argue that it placed Africa on a low-growth path, undermined economic diversification efforts, and led to an erosion of the industrial base in the region (Sundaram and von Arnim, 2008; Mkandawire, 2005; Soludo, Ogbu and Chang, 2004; Stein, 1992). In particular, the focus on liberalization of markets coupled with the phasing out of various forms of interventionist policies supporting manufacturing drove many domestic firms out of business. This resulted in the destruction of what remained of the local industry base despite the potential of technological upgrading in some of the existing domestic firms (Lall, 1995). In Mozambique, for example, the reduction in the strategic role of the State during the SAP period undermined attempts to promote industrial development. There is also evidence that in Ghana, Nigeria and Zambia, trade liberalization under SAP exposed domestic firms to import competition and led to the closure of some manufacturing firms (Lall and Mwangwe, 1998).

\subsubsection{The Poverty Reduction Strategy Papers (PRSP) phase}

By the second half of the 1990s, many African countries had accumulated enormous foreign debt and the burden of debt service became an obstacle to growth and development. In response to this challenge, in 1996 donors launched the Heavily Indebted Poor Countries (HIPC) initiative designed to provide relief to severely indebted countries. Dissatisfaction with the slow progress of the HIPC initiative in reducing the debt of poor countries led to the adoption of the enhanced HIPC initiative in 1999 (Booth, 2003). As a precondition for participation in the enhanced HIPC initiative, potential recipients were required to prepare PRSPs detailing how the resources made available through debt relief would be used to reduce poverty in the recipient country. In particular, recipient countries were encouraged to invest the resources from debt relief in the social sectors such as health and education (particularly at the primary and secondary levels). Consequently, since 2000, most African countries considered eligible for participation in the HIPC programme have prepared PRSPs, giving priority to spending on health as well as primary and secondary education. Therefore, the year 2000 marked the beginning of another phase of policy design and implementation that had implications for industrialization in the region.

The PRSP differs from the ISI and SAP in the sense that it was specifically designed as a debt relief programme, it is evident that it did have consequences for industrial development in Africa because the first generation PRSPs led to a shift of resources from the production to the social sectors. The second generation PRSPs tried to address the social sector bias problem associated with the first generation PRSPs. However, interest in the productive sectors in second generation PRSPs in Africa tends to be in agriculture and its related industries, reflecting largely the widespread view that African countries have a comparative advantage in these industries and that agriculture is an important source of growth. UNCTAD (2006).

\subsection{Necessity of Strong Infrastructure}

Recent research suggests that economic development requires structural change from low to high productivity activities and that the industrial sector is a key engine of growth in the development process (Lall, 2005; Rodrik, 2007; Hesse, 2008). Virtually all cases of high, rapid and sustained economic growth in modern economic development have been associated with industrialization, particularly growth in manufacturing production (Szirmai 2009). Commodity exports can lead to high but not sustained economic growth. The necessity of structural change also arises from the fact that Africa needs high and sustained economic growth in order to make significant progress in reducing poverty. One of the major challenges which African countries currently face is to generate productive jobs and livelihoods for the 7-10 million young people entering the labour force each year. This is difficult to achieve simply through commodity exports but rather requires a complementary process of agricultural productivity growth and development of non-agricultural employment opportunities in both industry and services. If African countries are to achieve substantial poverty reduction and also the Millennium Development Goals (MDGs), they have to go through a process of structural transformation involving a decrease in the share of agriculture and an increase in the share of industry and modern services in output, with a shift between and within sectors from lower productivity to higher productivity activities. 


\subsection{Institutional and governance issues}

An important constraint on effective industrial policy in Africa is weaknesses in governance capacities. Experience from East Asia has suggested two critical institutional ingredients for success. The first was the existence of an effective, dedicated and capable bureaucracy. The second was that State institutions operated in a situation of embedded autonomy in the sense that they were closely collaborating with the private sector to formulate and implement policy, but at the same time they were not influenced to favour particular interests. In Africa, State capacities for development policy formulation and implementation have been severely eroded and after years of neglect, ministries of industry are often weak. Against this background, some argue that however desirable an industrial policy is in Africa, it will only lead to huge societal costs owing to government failure. While it is important to be cognizant of the governance challenge of industrial policy, it is too pessimistic to argue that it is impossible. Firstly, it is clear from the East Asian success story that there was a deliberate strategy to build up a few strategically important agencies rather than to improve government effectiveness across the board. Also the capabilities of bureaucracies were built up over time,

With an emphasis on policy learning. This implies that an important feature of the development of industrial policies in Africa should be the adoption of policies to enhance government capabilities in managing the industrialization process. In addition, since most of the strategies and measures discussed imply some form of government intervention, there is

A need to take into account government capabilities in making decisions on the scope of intervention in an economy. In this regard, and given their limited capacity, African governments should not attempt the kind of pervasive interventions used in the past in the newly industrialized countries. They should be pragmatic and give priority to improving government capabilities for industrial diagnosis and strategy design, as well as policy formulation, implementation, monitoring and evaluation.

\subsection{Strengthening infrastructure development}

The inadequate and poor quality of infrastructure in Africa is a major obstacle to the development of competitive industries in the region. It is estimated that Africa loses 1 percentage point per year in per capita economic growth as a result of its infrastructure deficit. The infrastructure problem is evident in areas such as power, water supply, transport and communications, which are critical to the successful development of manufacturing enterprises. Furthermore, the problem is not limited to poor network coverage but also manifested in the exceptionally high price of infrastructure services in Africa relative to global standards (Figure 1). The high cost of infrastructure in Africa increases trade costs and reduces productivity of African firms by about 40 per cent (Foster and Briceno-Garmendia, 2010). Public investments will be needed to address Africa's infrastructure problem.

(i) Figure 1 Cost of Infrastructure In Africa

\begin{tabular}{|l|l|l|}
\hline & $\begin{array}{l}\text { Sub Sahara } \\
\text { Africa }\end{array}$ & $\begin{array}{l}\text { Other developing } \\
\text { countries }\end{array}$ \\
\hline $\begin{array}{l}\text { Power tariffs } \\
\text { \$ per kilowatt-hour) }\end{array}$ & $0.46-0.05$ & $0.02-0.1$ \\
\hline $\begin{array}{l}\text { Water tariffs } \\
\text { \$ per cubic meter) }\end{array}$ & $0.86-6.56$ & $0.03-0.6$ \\
\hline $\begin{array}{l}\text { Road freight tariffs } \\
\text { \$ per ton-kilometre }\end{array}$ & $0.04-0.14$ & $0.01-0.04$ \\
\hline $\begin{array}{l}\text { Mobile telephony } \\
\text { \$ per basket per month) }\end{array}$ & $2.6-21.0$ & 9.9 \\
\hline $\begin{array}{l}\text { International telephony } \\
\text { \$ per 3-minute call to the US) }\end{array}$ & $0.44-12.5$ & 2.0 \\
\hline $\begin{array}{l}\text { Internet dial-up service } \\
\text { (\$ per month) }\end{array}$ & $6.7-148.0$ & 11 \\
\hline
\end{tabular}

Source: Foster and Briceno-Garmendia (2010).

Note: Prices for international telephony and internet represent all developing countries, including Africa

However, since governments do not have the resources they need to address all infrastructure needs, the private sector should also be provided with incentives to either participate or contribute more to infrastructure development in the region. In addition, the setting up of special economic zones could enhance firms' access to infrastructure. When special economic zones are provided with good infrastructure, have management that is sensitive to the needs of firms and are supported with effective public institutions, they can be effective vehicles for promoting industrialization. Furthermore, African countries should be aware that not all 
manufacturing industries necessarily require the same infrastructure. Based on the selection of specific target sectors and in close consultation with the respective domestic private sector, a pragmatic prioritization of required improvements may thus be expedient.

\section{Metodology, Data And Source}

It makes sense to analyse the relative degree of structural transformation of African economies from the domestic as well as the international perspective in more detail. On the one hand, from the domestic production perspective two levels of transformation can be distinguished: (a) an increase in the relative contribution of manufacturing to the whole economy as well as (b) an increase in the relative contribution of more technology intensive manufacturing activities to total manufacturing. On the other hand, it is also necessary to look into the structure of African manufacturing exports, in order to understand the competitiveness of African manufactures in global markets. From this perspective, we can also distinguish between two levels of transformation:

(a) an increase in the relative contribution of manufacturing exports to total exports as well as

(b) an increase in the relative contribution of more technology intensive manufacturing exports to total manufacturing exports.

Panel data( combination of Cross sectional and Time series analysis) is applied on the data obtained by UNIDO from developing countries spanning from 1980-2010.

Data on the following variables were obtained,

- Relative contribution of manufacturing exports to total exports.

- Contribution of more technology intensive manufacturing exports to total manufacturing exports.

\subsection{EMPIRICAL ANALYSIS}

The validity of the hypothesis can be tested by estimating the following empirical specifications,
$W M \square \square \square \beta_{1} \square \square \square \beta_{2} Y \quad \ldots . . . . . . . . .(4.1)$
$W M \square \square \boldsymbol{\alpha} \square \boldsymbol{Y}^{+\boldsymbol{\beta}} \square \square$ expressed in terms of the natural logarithm, $\ln (\mathbf{W M}) \square \square \ln \square \square \beta \square \ln Y$ )

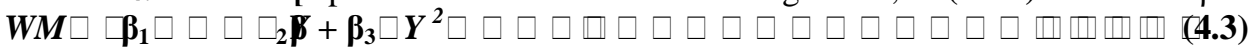

The dependent variable, WM, is defined as the total world manufactured goods(Global manufacturing). The explanatory variable is export manufactures. We test for three empirical specifications. First, we test for a monotonic relationship (Equation 4.1). We test for a negative exponential relationship (Equation 4.2); If Equation 4.2 is found to provide a better explanation given the data, this indicates that the incidence export manufactures exhibits a downward trend. Last, we test for a non-linear quadratic relationship (Equation 4.3). For the hypothesis to hold, $\beta_{2}>0$ and $\beta_{3}<0$ must be true.

Using panel data methodology, we propose to estimate fixed effects specification by pooled least squares (Hsiao, 1986; Judge et al, 1988). The cross sectional specific components are assumed to be fixed parameters. That is to say, each country has a unique constant term which captures the location specific factors. The equations can be written as,

$$
\begin{aligned}
& \mathrm{WM}=\sum_{j=1}^{N}\left(B_{i j} D_{j t}+B_{2} Y_{i t}+U_{i t}\right) \\
& \operatorname{Ln}(\mathrm{WM})=\sum_{j=1}^{N}\left(\ln \alpha_{i} D_{j t}+B \ln (Y)_{i t}+U_{i t}\right) \\
& \mathrm{WM}=\sum_{j=1}^{N}\left(B_{i j} D_{j t}+B_{2} Y_{i t}+B_{3} Y Z_{i t}+U_{i t}\right) \\
& \mathrm{U}_{\mathrm{it}} \cong \mathrm{iid}\left(0, \sigma^{2} \mathrm{u}\right) \\
& \forall \mathbf{I}=\mathbf{1} \ldots \ldots \ldots . \mathrm{N} \text { when } \mathrm{N} \text { refers to the number of cross sectional units } \\
& \forall=1 \ldots \ldots \ldots . . T \text { is the number of annual time period } \\
& \mathbf{B}_{\mathrm{ij}} \text { are the cross section fixed effects } \\
& \text { The dummy variables take the value of } 0 \text { or } 1 \text { corresponding to country that is being observed. } \\
& \mathbf{D}_{\mathbf{j t}}=\quad 1 \text { if } \mathrm{j}=1 \\
& 0 \text { if } j \quad 1 \neq 1
\end{aligned}
$$


The fixed effects specification is most appropriate to absorb any permanent differences across countries - such as government policy and legislation. Further, because the sample is not randomly drawn, we do not assume the cross-sectional specific effects to differ as a result of sampling error.

Equation 4.4 will be referred to as the linear model, we will refer to Equation 4.5 as the $\log -\log$ model and Equation 4.6 as the quadratic model.

\subsection{EMPIRICAL RESULTS}

The pooled regression result of the total export supply function for the Africa countries is shown in Figure 2. Although the model specification reflected the influence of market fundamentals by including income and prices, the variables of interest is the export rate and foreign reserve holdings. The question we seek to answer therefore, is "to what extent have the Afrcan countries contributed to the total world manufacture."

A preliminary interpretation of the regression result displayed in Figure 2 shows that on the aggregate, the regional export supply of these countries to the rest of the world is influenced positively by all the explanatory variables of the equation. This is consistent with the theoretical expectation. The negative sign of the parameter estimate of the foreign countries GDP (reflected in our model by that of the United States of America and other major exporters of manufactures) suggest that an inverse relationship exists between African exports and those of other developed countries. One may therefore be tempted to conclude (perhaps erroneously) that African exports( which ironically is dominated by primary sectors - mainly labour intensive manufacture and mining) competes with the other developed countries exports( which is dominated by secondary and tertiary economic activities. However the regression results of the Gambia, Nigeria, Guinea, and Ghana total export reveals that the signs of parameter estimate of the United States of America and other major exporters of manufactures) output with respect to these countries global exports supply is consistent with this African export of manufacture functions.

\begin{tabular}{|c|c|c|c|}
\hline \multicolumn{4}{|c|}{ (ii) Figure 2: Pooled Regression Results for Africa Export of Manufactures } \\
\hline \multirow{5}{*}{\multicolumn{4}{|c|}{$\begin{array}{l}\text { Dependent Variables: World Manufactures } \\
\text { Method: Pooled EGLS(Cross Sectional SUR) } \\
\text { Sample:1980:1 2010:4 } \\
\text { Included observation: } 57 \\
\text { Total Pooled( balanced) observations:116 } \\
\text { Linear estimation after one step weighing matrix }\end{array}$}} \\
\hline & & & \\
\hline & & & \\
\hline & & & \\
\hline & & & \\
\hline Variable & coefficient & t- stat & Prob. \\
\hline $\mathrm{C}$ & -0.56 & 0.4 & 0.67 \\
\hline $\mathrm{LOG}\left(\mathrm{Y}^{\mathrm{D}}\right)$ & 1.47 & 8.3 & 0.00 \\
\hline $\operatorname{LOG}\left(\mathrm{Y}^{\mathrm{F}}\right)$ & -2.71 & -6.0 & 0.00 \\
\hline $\operatorname{LOG}\left(\mathrm{P}^{\mathrm{D}}\right)$ & 0.85 & 4.6 & 0.00 \\
\hline $\operatorname{LOG}\left(\mathrm{P}^{\mathrm{F}}\right)$ & -0.86 & -5.8 & 0.00 \\
\hline $\mathrm{LOF}\left(\mathrm{FR}^{\mathrm{N}}\right)$ & 0.11 & 3.8 & 0.00 \\
\hline LOG(ER) & -0.22 & 5.9 & 0.00 \\
\hline \multicolumn{4}{|l|}{ Fixed effect(cross) } \\
\hline GAMBIA & -1.888 & & \\
\hline NIGERIA & 0.353 & & \\
\hline GHANA & 0.117 & & \\
\hline SIERA LEONE & 0.698 & & \\
\hline GUINEA & -2.227 & & \\
\hline \multicolumn{4}{|l|}{ Weighted Statistics } \\
\hline R-squared & 0.958 & & \\
\hline Adjusted R squared & 0.957 & & \\
\hline S.E of Regression & 0.955 & & \\
\hline F- statistic & 1019.5 & & \\
\hline Prob(F-stat) & 0 & & \\
\hline Mean dependent variable & & & 10.87 \\
\hline S.D. dependent variable & & & 14.83 \\
\hline Sum square residual & & & 409.42 \\
\hline D.W. Statistic & & & 0.59 \\
\hline
\end{tabular}

Interestingly, the sign and magnitude of the coefficient of the parameter estimate of the exports of manufactures is negative and significant but inelastic suggesting that it is limitedly responsive to the export of labour intensive manufactures. At $95 \%$ degree of freedom, we accept the null hypotheses, concluding that Africa did not contribute significantly to manufacturing exports to total exports and that no significant contribution of more technology intensive manufacturing exports to total manufacturing exports. The problem was accentuated during the pre-Structural Adjustment Programme (SAP) eras when in addition to overvalued exchange rate, domestic prices of export were implicitly taxed as major source of government revenue and hence discouraged export in post-SAP through export and excise duties. It was quite common that these 
countries individually adopted and intervened with free trade through the implementation of several non-tariff barriers as major instruments of trade policy. The growth rate of real output fell from an annual average of 5.2 per cent over the period 2000-2006 to 2.6 per cent in 2009. Similarly, the growth rate of real output per capita fell from 2.7 per cent to 0.3 per cent over the same period. The crises have also eroded recent gains made by African countries in poverty reduction and reduced prospects of achieving the Millennium Development Goals (MDG) by the target date (Osakwe 2010). The sign of the estimate parameters equally corroborate the finding of UNCTAD that "The export diversification index for the region fell slightly from 0.61 in 1995 to 0.58 in 2009 (UNCTAD 2003)

This low export of Africa manufacture can be related with the Structural change analysis which shows that the sectoral evolutionary path is conditioned by a country's development stage as well as exogenous factors (country size, factor endowments and population density). Based on these factors, individual sectors have different economic growth potentials. For instance, while some industries are more likely to support the rapid growth of LDCs, others are more important for middle-income or high-income countries. The same is true for small vs. large or resource rich vs. resource poor countries, and so forth. Heterogeneity amongst countries is an important feature of African manufacturing. In particular, there is a wide variance across countries in terms of both the level and growth of manufacturing value added MVA per capita. In 1990, 6 of the 52 African countries for which data are available had MVA per capita of at least \$200 and in 2010 the number of countries with an MVA per capita of at least $\$ 200$ was 9 . In terms of manufacturing growth, 23 African countries had negative MVA per capita growth over the period 1990-2010 and 5 countries had an MVA per capita growth above 4 per cent.(UNCTAD 2003)

\subsection{Empirical Analysis}

To further verify the empirical findings, The share of African manufacturing in GDP rose from 6.3 per cent in 1970 to a peak of 15.3 per cent in 1990 (Figure 3). Since then, there has been a significant decline in the contribution of manufacturing to GDP. In particular, the share of manufacturing in GDP fell from 15.3 per cent in 1990 to 12.8 per cent in 2000 and 10.5 per cent in 2010 . It is interesting to note that the decline in the contribution of manufacturing to GDP since 1990 has been observed in all sub regions of the continent. In Eastern Africa, the share of manufacturing in GDP fell from 13.4 per cent in 1990 to 9.7 per cent in 201.0 In West Africa it fell from 13.1 to 5 per cent over the same period. Furthermore, in Southern Africa, it fell from 22.9 to 18.2 per cent and in Northern Africa it fell from 13.4 to 10.7 per cent.

Africa continues to be marginalized in global manufacturing production and trade. The share of the region in global manufacturing value added fell from 1.2 per cent in 2000 to 1.1 per cent in 2010 . In developing Asia, it rose from 13 per cent to 25 per cent and in developing countries in Latin America it fell from 6 per cent to 5 per cent over the same period. There has also been no significant change in the region's share of global manufacturing exports in recent years. In particular, while Africa's share of global manufacturing exports rose slightly from 1 per cent in 2000 to 1.3 per cent in 2010, in low- and middle-income countries in East Asia and the Pacific it rose from 9.5 per cent in 2000 to 16 per cent in 2010. Furthermore, in low and middle-income countries in Latin America it fell from 5 per cent to 4.5 per cent over the same period. These facts suggest that African countries have not taken full advantage of the opportunities offered by manufacturing for growth and development. They also suggest that the region continues to be marginalized in global manufacturing trade.

(iii) Figure 3 Contribution of Industry to GDP from 1970 to 2010

\begin{tabular}{|c|c|c|c|c|c|c|c|}
\hline & \% share of GDP & 1970 & 1980 & 1990 & 2000 & 2005 & 2010 \\
\hline World & $\begin{array}{l}\text { Industry } \\
\text { Manufacturing } \\
\text { Mining \& Utilities }\end{array}$ & $\begin{array}{l}36.9 \\
26.7 \\
3.9 \\
\end{array}$ & $\begin{array}{l}38.1 \\
24.4 \\
7.1\end{array}$ & $\begin{array}{l}33.3 \\
21.7 \\
5.2 \\
\end{array}$ & $\begin{array}{l}29.1 \\
19.2 \\
4.5\end{array}$ & $\begin{array}{l}28.8 \\
17.8 \\
5.5\end{array}$ & $\begin{array}{l}30.1 \\
18.1 \\
6.2 \\
\end{array}$ \\
\hline $\begin{array}{l}\text { Africa Developing } \\
\text { Economy }\end{array}$ & $\begin{array}{l}\text { Industry } \\
\text { Manufacturing } \\
\text { Mining \& Utilities }\end{array}$ & $\begin{array}{l}13.1 \\
6.3 \\
4.8 \\
\end{array}$ & $\begin{array}{l}35.6 \\
11.9 \\
19.3\end{array}$ & $\begin{array}{l}35.2 \\
15.3 \\
15.2\end{array}$ & $\begin{array}{l}35.5 \\
12.8 \\
18.4\end{array}$ & $\begin{array}{l}38.8 \\
11.6 \\
23.0\end{array}$ & $\begin{array}{l}40.7 \\
10.5 \\
25.8\end{array}$ \\
\hline Eastern Africa & $\begin{array}{l}\text { Industry } \\
\text { Manufacturing } \\
\text { Mining \& Utilities }\end{array}$ & $\begin{array}{l}3.1 \\
1.7 \\
0.8\end{array}$ & $\begin{array}{l}7.8 \\
4.9 \\
1.5\end{array}$ & $\begin{array}{l}20.6 \\
13.4 \\
3.3 \\
\end{array}$ & $\begin{array}{l}18.6 \\
10.4 \\
3.1 \\
\end{array}$ & $\begin{array}{l}20.6 \\
10.3 \\
3.6\end{array}$ & $\begin{array}{l}20.3 \\
9.7 \\
3.7 \\
\end{array}$ \\
\hline Middle Africa & $\begin{array}{l}\text { Industry } \\
\text { Manufacturing } \\
\text { Mining \& Utilities }\end{array}$ & $\begin{array}{l}34.2 \\
10.3 \\
19.1\end{array}$ & $\begin{array}{l}38.4 \\
11.8 \\
21.2\end{array}$ & $\begin{array}{l}34.1 \\
11.2 \\
18.9\end{array}$ & $\begin{array}{l}50.4 \\
8.2 \\
39.3 \\
\end{array}$ & $\begin{array}{l}57.9 \\
7.3 \\
47.9\end{array}$ & $\begin{array}{l}59.8 \\
6.4 \\
50.5 \\
\end{array}$ \\
\hline Southern Africa & $\begin{array}{l}\text { Industry } \\
\text { Manufacturing }\end{array}$ & $\begin{array}{l}38.2 \\
22.0\end{array}$ & $\begin{array}{l}48.2 \\
20.9\end{array}$ & $\begin{array}{l}40.6 \\
22.9\end{array}$ & $\begin{array}{l}32.7 \\
18.4\end{array}$ & $\begin{array}{l}31.7 \\
17.9\end{array}$ & $\begin{array}{l}34.5 \\
18.2\end{array}$ \\
\hline
\end{tabular}




\begin{tabular}{|l|l|l|l|l|l|l|l|}
\hline & Mining \& Utilities & 12.0 & 24.0 & 14.3 & 11.7 & 11.2 \\
\hline Western Africa & Industry & 26.7 & 43.3 & 34.5 & 39.8 & 36.7 & 37.4 \\
& Manufacturing & 13.3 & 16.8 & 13.1 & 7.8 & 6.0 & 5.0 \\
& Mining \& Utilities & 7.7 & 21.3 & 18.8 & 29.3 & 27.7 \\
\hline
\end{tabular}

\section{Source: Author's from UNCTAD/UNIDO}

One of the important features of manufacturing in Africa today is that, relative to other developing economies, the sector plays a very limited role in African economies. In particular, the share of manufacturing value added (MVA) in Africa's GDP is small relative to what is observed in other developing-country regions. In 2000, manufacturing accounted for 12.8 per cent of GDP in the region and in 2010 it accounted for 10.5 per cent. Unlike the situation in Africa, manufacturing seems to play a more important role in economic activities in both developing Asia and Latin America. In Asia, the share of MVA in GDP rose from 22 per cent in 2000 to 35 per cent in 2010 while in Latin America it fell from 17 per cent to 16 per cent over the same period. The slow pace of manufacturing development in Africa is also evident at the international level. Manufacturing exports represent a relatively low percentage of total African exports and, more importantly, the share has declined over the years. While the share of manufactures in Africa's exports was 43 per cent in 2000, it fell to 39 per cent in 2010. The decline in the importance of manufacturing in Africa's exports can be explained in part by the growing trade between Africa and non-African developing countries, which has led to a substantial increase in commodity exports in recent years. It should be noted that the share of manufacturing exports in Africa's total exports is also low when compared to other

developing regions. For example, in 2010, the share of manufacturing exports in total exports was 89 per cent in low and middle income countries in East Asia and the Pacific, 61 per cent in low and middle income countries in Latin America, and 85 per cent in low- and middle-income countries in South Asia.

\section{Findings}

The findings from this paper are summarized thus:-

1. Manufacturing currently plays a limited role in African economies. The share of manufacturing value added (MVA) in Africa's GDP fell from 12.8 per cent in 2000 to 10.5 per cent in 2010. In Latin America, it fell from 17 per cent to 16 per cent and in developing Asia, it rose from 22 per cent to 35 per cent over the same period. There has also been a decline in the importance of manufacturing in Africa's exports. In particular, the share of manufactures in Africa's total exports fell from 43 per cent in 2000 to 39 per cent in 2010.

Factors that have contributed to Africa's weak industrial performance include domestic policy failures, lack of policy space to implement alternative development policies and structural constraints such as poor infrastructure, low human capital and the small size of domestic markets.

2. Africa still accounts for a low share of global manufacturing. Africa continues to be marginalized in global manufacturing trade. The share of the region in global MVA fell from 1.2 per cent in 2000 to 1.1 per cent in 2008. In developing Asia it rose from 13 per cent to 25 per cent and in Latin America it fell from 6 per cent to 5 per cent over the same period. In terms of exports, Africa's share of global manufacturing exports rose from 1 per cent in 2000 to 1.3 per cent in 2010.

3. Africa is losing ground in labour-intensive manufacturing. Low technology and labour-intensive manufactures play a limited role in African manufacturing. The share of low technology manufacturing activities in MVA fell from 23 per cent in 2000 to 20 per cent in 2010. Furthermore, the share of low technology manufacturing exports in Africa's total manufacturing exports dropped from 25 per cent in 2000 to 18 per cent in 2010 .

4. Africa is heavily dependent on Resource $B a s e(R B)$ manufacturing. Africa is heavily dependent on RB manufactures. In particular, the share of RB manufactures in Africa's total manufacturing exports was 52 per cent in 2000 and 49 per cent in 2010. This contrasts with the situation in Latin America, and East Asia and the Pacific, where the shares of RB in total manufacturing exports in 2010 were 34 per cent and 13 per cent, respectively.

5. African manufacturing is dominated by small and informal firms. In most African countries, the manufacturing sector is made up of small or microenterprises operating side by side with a small number of large foreign or State-owned firms. Furthermore, most enterprises are informal firms. Informal firms are smaller in size, produce to order, are run by managers with low human capital, do not have access to external finance, do not advertise their products and sell to largely informal clients for cash. In addition, informal firms rarely become formal as they grow. 


\subsection{Recommendations}

African countries require high and sustained economic growth to make significant progress in reducing poverty and engender development. But history and econometric evidence have shown that the prospects for high and sustained growth in any country depend largely on the degree of structural transformation of the economy. No country has achieved high and sustained economic growth without going through a process of structural transformation, characterized by a shift of production and exports from low productivity to high productivity goods. This suggests that what a country produces and exports matter for growth and development (Hausmann, Hwang and Rodrik, 2007).

Furthermore, one of the major challenges which African countries currently face is to generate productive jobs and livelihoods for the 7-10 million young people entering the labour force each year. This is difficult to achieve simply through commodity exports. It requires a complementary process of agricultural productivity growth and development of non-agricultural employment opportunities in both industry and services. If African countries are to achieve substantial poverty reduction and other MDGs, they must go through a process of structural transformation involving a decrease in the share of agriculture and an increase in the share of industry and modern services in output, with a shift between and within sectors from lower productivity activities to higher productivity activities. African governments are aware of this reality and have taken several steps in recent years to renew their commitment to industrialization. But the question is how they can do this without repeating the mistakes of the past.

Efforts to promote industrial development in Africa should be centered on (a) promoting scientific and technological innovation, (b) creating linkages in the domestic economy, (c) fostering entrepreneurship, (d) improving government capabilities, (e) adopting appropriate monetary and fiscal policies, (f) avoiding exchange rate overvaluation, (g) enhancing resource mobilization, (h) strengthening regional integration and (i) maintaining political stability.

\section{Closing Remarks}

Industrial development is crucial for sustained growth and poverty reduction in Africa. Over the past decade, African governments have renewed their political commitments to industrialization and have adopted several initiatives at the national and regional levels to enhance prospects of achieving their objectives. This paper welcomes the new developments and argues that the optimal industrialization path and policies will vary across African countries because of differences in endowments, political conditions and geography. Furthermore, a new industrial policy is needed to induce structural transformation and engender development in African economies.

\section{References}

[1]. Booth D (2003). Are PRSP's making a difference? The African experience: introduction and overview. Development Policy Review. 21(2).

[2]. Chang H (2009). Industrial policy: can we go beyond an unproductive confrontation? Bank Conference on development Economics, Seoul, Republic of Korea, 22-24 June.

[3]. Foster V and Briceno-Garmendia C (2010). Africa's infrastructure: a time for transformation. World Bank. Washington D.C.

[4]. Gault F and Zhang G (2010). The role of innovation in the area of development. In: Kraemer-Mbula E and Wamae W, eds. Innovation and the Development Agenda. OECD/IDRC. Paris.

[5]. Hausmann R, Hwang J and Rodrik D (2007). What you export matters. Journal of Economic Growth. 12(1): 1-25.

[6]. Hesse H (2008). Export diversification and economic growth. Working Paper No. 21, Commission on Growth and Development. [7]. Kaplinsky R (2007). Capacity-building in SSA: what difference do the Asian Drivers make?
meeting of Experts on FDI, Technology and Competitiveness held at UNCTAD, Geneva, 8-9 March.

[8]. Lall S (1995). Structural adjustment and African industry. World Development. 23(12): $2019-2031$.

[9]. Lall S (2005). Is African industry competing? Working Paper 121. Queen Elizabeth House, University of Oxford.

[10]. Lall S and Teubal M (1998). Market-stimulating technology policies in developing countries: a framework with examples from East Asia. World Development. 26(8): 1369-1385.

[11]. Lall S and Wangwe S (1998). Industrial policy and industrialisation in sub-Saharan Africa. Journal of African Economies. 7(1):70-107.

[12]. Mkandawire T and Soludo C (2003). African Voices on Structural Adjustment: A Companion to Our Continent, Our Future. Africa World Press, Inc. Trenton.

[13]. Osakwe P and Schembri L (2002). Real effects of collapsing exchange rate regimes: an application to Mexico. Journal of International Economics. 57: 299-325.

[14]. Osakwe P N (2010). Africa and the global financial and economic crisis: impacts, responses and opportunities. In: Dullien S, Kotte D, Marquez A and Priewe J, eds.

Financial and Economic Crisis of 2008-2009 and the Developing Countries. United Nations and HTW Berlin University of Applied Sciences. New York.

[15]. Ramachandran V, Gelb A and Shah M K (2009). Africa's private sector: what's wrong with the business environment and what to do about it. Centre for Global Development. Washington, D.C.

[16]. Rodrik D (2004). Industrial policy for the twenty-first century. CEPR Discussion Paper Research. London.

[17]. Rodrik D (2007). Industrial development: some stylized facts and policy directions. In: No. 4767. Centre for Economic Policy Development for the 21st Century. United Nations. New York.

United Nations, eds. Industrial 
[18]. Shen J, Dunn D and Shen Y (2007). Challenges facing U.S. Manufacturing and Strategies. Journal of Industrial Technology. 23(2): $2-10$

Soludo C, Ogbu O and Chang H (2004). The Politics of Trade and Industrial Policy in Africa. Africa World Press. Trenton.

[19]. Stein H (1992). De-industrialization, adjustment, the World Bank and the IMF in Africa. World Development. 20(1):83-95.

[20]. Sundaram J and von Arnim R (2008). Economic liberalization and constraints to development in sub-Saharan Africa. DESA Working Paper No. 67.

Sutton J and Kellow N (2010). The Enterprise Map Project. An Enterprise Map of Ethiopia. IGC. London.

[21]. Szirmai A (2009). Industrialization as an engine of growth in developing countries. UNUMerit Working Papers 2009-010. Third World Network (2009). Benefits of exports taxes. Preliminary paper. Geneva.

[22]. UNCTAD (2003). Trade preferences for LDCs: an early assessment of benefits and possible improvements. United Nations publication, Geneva.

[23]. UNCTAD (2004). Trade and Development Report 2004. Policy Coherence, Development Strategies and Integration into the World Economy. United Nations publication. Geneva.

[24]. UNCTAD (2006). Economic Development in Africa Report 2006. Doubling Aid: Making the Big Push Work. United Nations publication, Sales No. E.06.II.D.10, New York and Geneva.

[25]. UNCTAD (2008). Trade and Development Report 2008. Commodity prices, capital flows and the financing of investment. United Nations publication, Sales No. E.08.II.D.21, New York and Geneva.

[26]. UNIDO/ UNCTAD (2011). Industrial Development Report 2011. UNIDO.Vienna.

[27]. Wangwe S and Semboja H (2003). Impact of structural adjustment on industrialization and technology in Africa. In: Mkandawire T and Soludo C, eds. African Voices on Structural Adjustment: A Companion to Our Continent, Our Future. Africa World Press, Inc. Trenton.

[28]. WTO (2010). Timeliness and contract enforceability in intermediate goods trade. Gamberoni E, Lanz R and Piermartini R. Staff Working Paper ERSD-2010-14.Economic Research and Statistics Division. World Trade Organization. Geneva. 